\title{
GIS use in solving water supplying and water environmental problems of Urban Territories
}

\author{
Nadezhda Kurepina $^{1, *}$ and Irina Rybkina ${ }^{1}$ \\ ${ }^{1}$ Institute of Water and Environmental Problems of the Siberian Branch of the Russian Academy of \\ Sciences (IWEP SB RAS), 656038, Russia
}

\begin{abstract}
Geoinformation systems (GIS) are actively used in modern scientific research, including the field of Urban Territories' management. The lack of a universal methodology for their application requires an individual approach in the study of water management and water and environmental problems in the region. The purpose of this article is to demonstrate concrete examples of GIS successful use in solving some water supplying problems. One of the leading research methods is geoinformation-cartographic modeling, which has a wide range of possibilities and contributes to the effective solution of water-related and water-ecological regional problems. The developed algorithm for GIS using in solving regional water, a step-by-step procedure organizes for carrying out research work, the presented structure of the thematic database facilitates the systematizatin of thematic data large volume with the base a GIS project is created, where information is integrated, calculations, and a cartographic model is created that visualizes the regional water management and water-e logical situation. The research examples carried out in the Institute of Hydrometeorology of the Russian Academy of Sciences (Siberian Branch) on regional water management and water ecological problems by means of GIS and using the method of geoinformationcartographic modeling considered in this paper prove the effectiveness and their use expediency.
\end{abstract}

\section{Introduction}

Modern software and computer technologies are used in virtually all spheres of human activity. In order to solve a wide range of scientific and practical problems in the nature management field, GIS, created on the information technologies in the Earth sciences basis, has successfully applied. GIS is actively applied in solving issues related to water and water environmental regional problems, and all the functionalities offered by GIS are in demand: input of data into the computer (by importing or digitizing them), converting data (converting data to the required format, transforming cartographic projections, change of coordinate systems); cartometric operations (calculation of coordinates, distances, areas, etc.), geodata spatial analysis (selection of objects, spatial queries, overlays, etc.), data

\footnotetext{
*Corresponding author: iwep@iwep.ru
} 
storage and management in a database (DB), visualization of data (output of results in different forms).

However, it should be noted that a universal methodology for GIS use is not available and an individual project-oriented approach is required in the study of water management and water environmental problems in the region. The purpose of this article is to demonstrate the capabilities of GIS-technologies in these problems' study. The following tasks are solved: development of an algorithm for the operational actions sequence in the GIS; development of the thematic database (DB) structure and its content; GIS project creation for water management and water-ecological orientation; interpretation and visualization of quantitative and qualitative data for the water management and water environmental problems assessment in the region. [1,2,3]

Nowadays, there are many scientific developments devoted to GIS use in solving various water management tasks. So, the types of GIS and their application are considered in the work of Yu.B. Shcherbinina (2006), on the example of Perm Region, summarized GIS projects of water use are presented, within the framework, which heterogeneous systems' databases were converted into a single information environment. In M.I. Vasilyeva, S.V. Plekhanova K.R. Khamitova (2008) article the development of software for the integration of water users' information systems and GIS of Russian Water Resources are described. The studies on the assessment of water use systems' sustainability and monitoring of water resources uses with the help of GIS (Nikanorova, 2014; Beshentsev, Tsibudeeva, 2015) are of interest. [4,5]

At the Institute of Water and Environmental Problems of the SB RAS (Barnaul) research works on water management and water resources have been carrying out for 30 years. A considerable amount of experience in geoinformation and cartographic modeling of regional water use was accumulated by a great number of scientists. This is only a small part of the work that is being done in this direction

\section{Materials and Methods}

The complex of heterogeneous data obtained from different sources (the Federal Agency for Water Resources, the Federal State Statistics Service, and Russian hydro met.) as well as cartographic materials are involved in solving the water and environmental problems of the region.

The generalization of spatially-oriented information is carried out at three hierarchical levels: macro-regional, regional and sub-regional. So, the subregional level corresponds administratively to the municipal districts of the subjects, to the physiographic or landscape provinces (in nature), to separate sections of the river water management division and hydrogeological basins (in water management). The regional level covers, respectively, the Siberian Federal District (SFR) subjects, the zonal-provincial division of the West Siberian Physical-geographical country and the Altai-Sayan mountain system, as well as the basin districts. The macro-regional level allows us to generalize information on water management problems for the SFR, presenting the characteristics in general for Western Siberia or the Ob-Irtysh basin.

The algorithm for GIS using to solve the tasks is presented in Figure 1. The first block is the "information input unit", as a rule, contains a large heterogeneous data complex of various formats: tabular, text, cartographic, which systematization and unification is required. The solution of this task is successfully carried out in GIS "primary information processing unit", where it (primary information) is converted into a working data set with spatial and time reference.

In the next "integration of information and analytical calculations" depending on the setting of the water management task, geodata spatial analysis is performed and 
computational operations with their quantitative characteristics are carried out. In order to solve water and water and environmental issues, a comprehensive approach and qualified specialists involvement of different profiles is needed, therefore, the planning and decisionmaking processes for accomplishing tasks are collegial. "The expert evaluation unit" is an organization of experts (different specialists) summarizing the results of geodata processing and calculations, formation and evaluation of decisions. "The visualization block of analytical calculations and examinations" is final. Thanks to the mapping of research results in geoinformation form and cartographic models, the perception of the final decision on water management and water environmental issues is greatly simplified. In some cases, due to the acquisition of new knowledge during visualization, the final decision is refined and corrected.

The algorithm of GIS use is implemented on the platform of the Arc GIS 10.2 (ESRI®) software product, the thematic DB is formed here, GIS-projects of water management and water ecological orientation are created; there is an interpretation of quantitative and qualitative data and design geo information and cartographical models. As operational estimated units act natural (landscape provinces (Vinokurov, Tsimbaly, 2006); river basins and water management sites (WMS) (the Order MWR of the Russian Federation from $4 / 25 / 2007$ N. 111)) and administrative territories, depending on an objective

\section{Results}

In this section, according to the research projects held in the Institute of Theoretical and Applied Mechanics of the Russian Academy of Sciences (Siberian Branch): "Spatiotemporal organization of natural-economic systems in watersheds: a strategy for water use and ensuring hydroecological safety in Siberia" (2013-2016); " Research of the current state and scientific substantiation and means for ensuring the sustainable functioning of the methods water management complex in the Ob and Irtysh rivers basins " (2008-2010) and "Formation, transformation and use of water resources, development of scientific bases for their protection and management based on the basin approach (taking into account natural, anthropogenic factors and features of nature management) "(2010-2012) demonstrates the results of GIS application in solving water and waterenvironmental problems in the region.

To systematize the vast amount of information that provides design works execution, the structure of the thematic DB of GIS was developed and its content was implemented. The created database of initial spatial data consists of three blocks (Figure 2). The natural block includes characteristics of natural resources of surface and groundwater, water management indicators of water resources use according to the State reporting (2tp. of water supplying) statistical forms, as well as calculated specific values of water consumption and water capacity, etc. The social and economic block of the database included population parameters in the section settlements, the size and number of urban districts and rural settlements of the study regions, the value of the gross regional product (GRP) indicators by economic activity types in the context of municipal entities and other entities. 


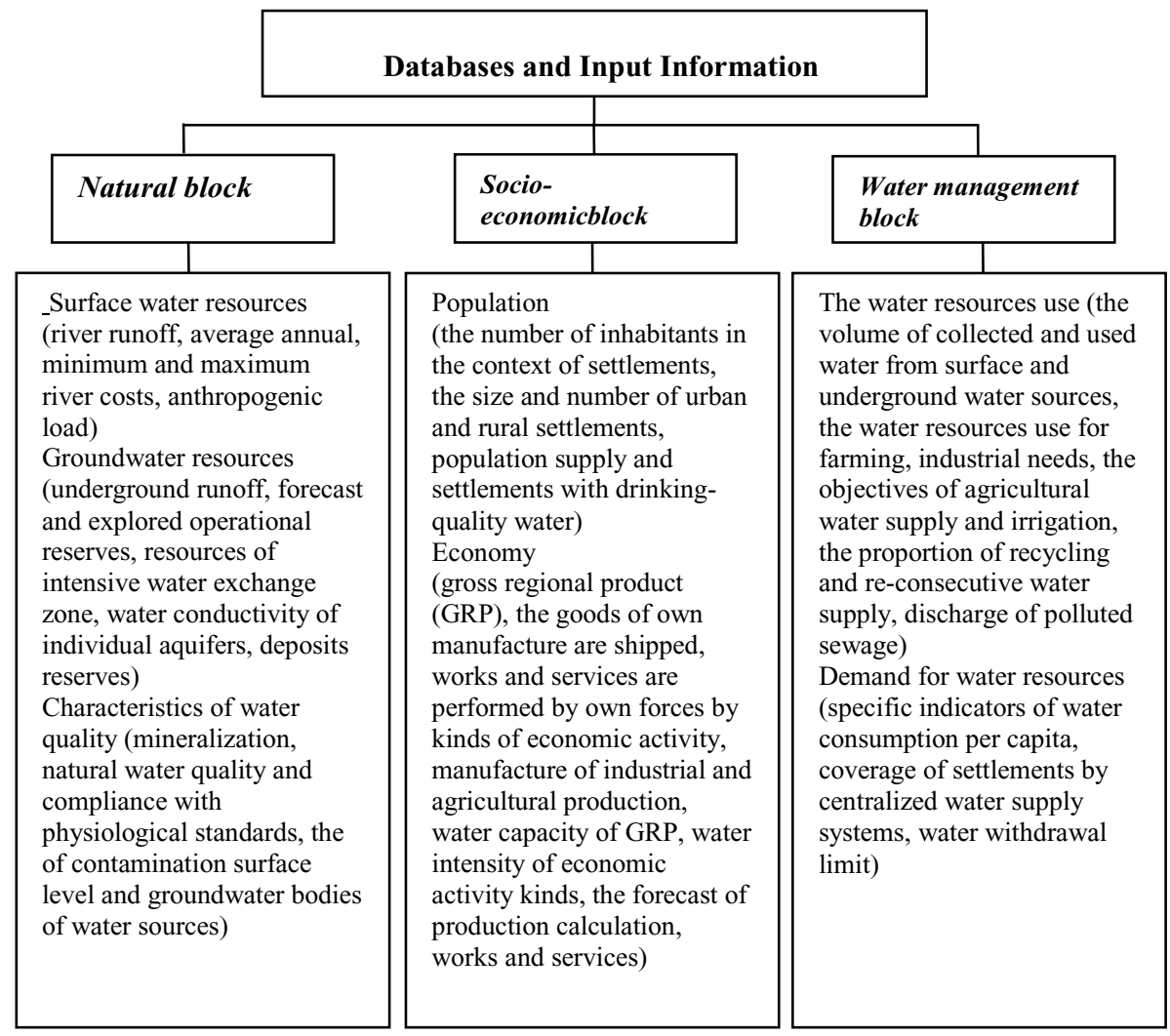

Fig. 2 Databases and Input Information

On the basis of the database, a GIS project was created for each research one: "Water availability of natural and economic systems in Western Siberia"; "Zoning (ranking) of the catchment area according to the anthropogenic pressure degree on water bodies of the $\mathrm{Ob}$ Irtysh basin", "Territorial organization of water use in the the Aley river basin. ". For example, the structure of the GIS project "Territorial organization of water use in the Alley of the river basin." is represented by three thematic blocks of spatial data (Figure 3). The first block of "Basic Geographic Basis" includes vector layers of the study territory geograpy and administrative entities, the second block "Landscape-basin structure" contains data of physico-geographical provinces and water management areas, the third block "Water use" is a complex of evaluation data divided into characteristics waterresource provision (underground and surface waters), water use systems (large-focal, focal, dispersed, linear and linear-area) and water resources use.

In accordance with the research task being solved, each GIS project carried out its own interpretation of quantitative and qualitative data. By quantitative indicators, a qualitative characteristic of the studied territories was established. Thus, water security in the Western Siberia regions was estimated from the water supply standpoint (Rybkina et al., 2016). In terms of the potential water availability magnitude (surface runoff) within the boundaries of natural and administrative units, the danger degree of the water management situation was determined

Zoning (ranking) of the Ob-Irtysh basin catchment area according to the anthropogenic load degree on water bodies was performed on the basis of the impacts' intensity 
characteristics, determined by indicators of population density, density of industrial production, plowing and livestock load (Figure 5).

In the GIS project "Territorial organization of water use in the Alley River basin complex of quantitative indicators obtained as a result of computational operations with initial data (table), served as a basis for the allocation of regional water use systems (largefocal, focal, linear, linear-area and dispersed).

Table 1. Interpretation of quantitative and qualitative data "Water use" block of the Aley River basin.

\begin{tabular}{|c|c|c|}
\hline \multirow{2}{*}{$\begin{array}{c}\text { System } \\
\text { water } \\
\text { use }\end{array}$} & \multicolumn{2}{|r|}{ Spatial data } \\
\hline & A source & Indicators (initial and estimated) \\
\hline \multirow{13}{*}{ 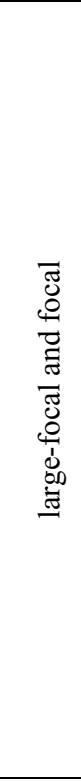 } & \multirow{6}{*}{$\begin{array}{l}\text { generalized data of the } \\
\text { state statistical } \\
\text { reporting } 2 \text { t. "water } \\
\text { economy" of the } \\
\text { Federal Agency of } \\
\text { Water Resources }\end{array}$} & $\begin{array}{l}\text { water abstraction from surface and underground sources, } \\
\text { mln } \mathrm{m} 3\end{array}$ \\
\hline & & $\begin{array}{l}\text { use of water for domestic and drinking, production needs, } \\
\text { irrigation and agricultural water supply, million m3 }\end{array}$ \\
\hline & & wastewater discharge, million $\mathrm{m} 3$ \\
\hline & & discharge to surface water sources, million $\mathrm{m} 3$ \\
\hline & & $\begin{array}{l}\text { discharge of contaminated sewage into surface water } \\
\text { sources, million } \mathrm{m} 3\end{array}$ \\
\hline & & $\begin{array}{l}\text { ischarge of normatively treated sewage into surface water } \\
\text { sources, million } \mathrm{m} 3\end{array}$ \\
\hline & \multirow{7}{*}{$\begin{array}{l}\text { socio-economic data of } \\
\text { the Federal State } \\
\text { Statistics Service for } \\
\text { municipalities }\end{array}$} & $\begin{array}{l}\text { water consumption of gross regional product (GRP), m3 / } \\
\text { thous. rub. }\end{array}$ \\
\hline & & $\begin{array}{l}\text { water capacity of GRP of industrial production, } \mathrm{m} 3 \text { / } \\
\text { thousand rubles }\end{array}$ \\
\hline & & $\begin{array}{l}\text { water intensity of the GRP of agricultural production, } \mathrm{m} 3 \text { / } \\
\text { thousand rubles. }\end{array}$ \\
\hline & & length of water supply and sewerage networks, $\mathrm{km}$ \\
\hline & & total water loss, $\mathrm{mln} \mathrm{m} 3$ \\
\hline & & $\begin{array}{l}\text { water loss in relation to the total volume of water } \\
\text { withdrawn, } \%\end{array}$ \\
\hline & & circulating and re-consecutive water supply, million $\mathrm{m} 3$ \\
\hline$\underset{\text { rse }}{\text { dispe }}$ & $\begin{array}{l}\text { data 2tp "water supply" } \\
\text { of the Federal Agency } \\
\text { for Water Resources }\end{array}$ & volume of water consumption for household needs, $\mathrm{mln} \mathrm{m} 3$ \\
\hline \multirow{2}{*}{ linear } & \multirow{2}{*}{$\begin{array}{l}\text { data of JSC "Altai } \\
\text { Water Management" }\end{array}$} & volume of water intake, $\mathrm{mln} \mathrm{m} 3$ \\
\hline & & volume of transported water, $\mathrm{mln} \mathrm{m} 3$ \\
\hline \multirow{3}{*}{$\begin{array}{l}\text { linear } \\
\text {-area }\end{array}$} & \multirow{3}{*}{$\begin{array}{l}\text { data of FGU } \\
\text { "Маnagement" } \\
\text { «Алтаймелиоводхоз» } \\
\text { « Altaymeliovodkhoz » }\end{array}$} & volume of water intake, $\mathrm{mln} \mathrm{m} 3$ \\
\hline & & volume of transported water, $\mathrm{mln} \mathrm{m} 3$ \\
\hline & & area of irrigated land \\
\hline
\end{tabular}

The results obtained visualization in the course of water management studying and water resource problems of the region is important for their perception, a deeper understanding, and in some cases, the acquisition of new knowledge. The created geoinformation-cartographic models are mostly original, because to display a complex of data requires an individual approach to the development of their content and layout. Thus, in the process of the water availability assessing of the Western Siberia natural-economic systems, a series of cartographic models was developed in GIS: territories ranking according to the degree of surface water resources availability; ranking of territories by the provision degree with underground water resources; potential supply of water resources to the landscape of Western Siberia provinces; the multiplicity of wastewater dilution with 
surface waters of the Ob-Irtysh basin in the context of landscape provinces (Kurepina, 2017, Kurepina, Rybkin, 2017, Fig. 6. [6,7,8]

A series of water resource and water-economic cards in the atlas form was created under the "Research of the current state and scientific substantiation of methods and means for ensuring the sustainable functioning of the water management complex in the basins of the $\mathrm{Ob}$ and Irtysh rivers" project. One of the atlas sections was maps of the Ob-Irtysh catchment area zoning (ranking) according to the anthropogenic load degree on the water objects of GIS model and the entire basin (Rybkin, Stoyaschev, Kurepina, 2011). An indicator of anthropogenic load intensity, indicators of water use by the water abstraction volume, indicating the source (surface or underground), and also by the volume of wastewater discharge (total, surface water bodies, contaminated, regulatory eyes waste, normative-clean sewage) were shown on the WWD level. $[9,10,11,12]$

In order to identify and visualize water-related and water-ecological problems in the region within the river basin boundaries, a mapping model was created in the GIS environment, reflecting the territorial organization of water use, taking into account the prevailing water consumption and sanitation characteristics (Vinokurov et al., 2014). The main content of the model is the characteristics of the regional water use systems and water availability of the river basin territories for municipalities and landscape provinces.

Geoinformation-cartographic models: a) assessment of administrative-territorial entities (subjects of the Russian Federation) of Western Siberia in terms of danger degree and risk of water use (fragment); b) zoning (ranking) of the catchment area according to the anthropogenic load intensity (WCS 13.01.02.001) [13-15]

\section{Discussion}

Presented GIS use results for studying a number of water management and water and environmental problems in the region, including: 1) uneven spatial distribution visualization of natural resource potential (location of water and water-deficit territories) and their qualitative and quantitative assessment; 2) development of a methodology for mapping in the GIS environment of an integrated water resource and water-ecological (taking into account the anthropogenic load) situation in the large river basins' territory to support the management decisions adoption; 3) territorial organization of water use in river basins, demonstrate the wide possibilities of modern software and technologies, but it should be noted a number of organizational and technical difficulties that we have to face. For example, the combination and analysis of heterogeneous data presented in natural and administrative-territorial boundaries, which can not always be solved in GIS; automated ways absence of thematic data generalization at different scales of cartographic modeling; lack of a single information base of water and water resources; limited access to source data on water users; lack of hydrological information due to network reduction of stationary observation posts. All these problems have to be solved on an individual basis. $[7,18]$

\section{Conclusions}

Modern software and computer technologies are effective in addressing issues related to water management and water environmental regional problems. With the use of GIStechnologies, all the functional capabilities that optimize scientific research in this field are in demand.

In accordance with the developed algorithm of the operational actions sequence in GIS, a step-by-step procedure for performing research work is rationally organized, starting with 
input of initial data and processing, further information integration, analytical calculations and expert evaluation of the results obtained before the final data visualization.

The development of the thematic database structure facilitates the systematization of a large thematic data volume, and the possibility of replenishing them makes it possible to carry out the research comprehensively, in the process of obtaining reliable results.

The creation of a GIS project forms a single geospatial field with DB information data for further processing, obtaining quantitative and qualitative characteristics, and their interpretation.

The organization of the GIS project data and their visualization in the geoinformationcartographic model format makes it possible to identify and assess of the territorial distribution of the natural resource potential (water location and water-deficit territories), perform a comprehensive water resource and water-ecological assessment of the territory in insufficient provision conditions of stationary observations, and its zoning (ranking) according to the anthropogenic load degree, to check up the river water management situation and identify priorities for solving water problems.

The considered examples of scientific research prove the expediency of GIS using in solving water and water environmental problems in the region, and the applied method of geoinformation-cartographic modeling contributes to their integral representation.

\section{References}

1. N. Beshentsev, D.C. Tibodeau, Geodesy and cartography, 4, 41-47 (2015)

2. M.I. Vasilyev, S.V. Plekhanov, R.K. Khamitov Software Development integration in GIS the Federal water resources Agency in the formation of a single information space in water management sphere, Ufa: GOU VPO Ufa state aviation technical University, 130-137 (2008)

3. G.V. Veduchina, I.N. Rotanova, Ecological mapping and GIS for solving the problems of water management in Altai region (Altai fair, Barnaul, 2008)

4. Y. I. Vinokurov, Y. M. Cimbalaб Regional landscape structure of Siberia (ASU, Barnaul, 2006)

5. Y.I. Vinokurov, I.D. Rybkin, N.I. Stoxev, N.Yu. Kurepina, Geography and natural resources, 133-140 (2014)

6. N.Yu. Kurepina, Proc. of Conf. GEO-Siberia-2011, 1, Novosibirsk, 216-220 (2011)

7. N.Yu. Kurepina, Proc. of Conf. GEO-Siberia-2017, Novosibirsk, 2, 58-64 (2017)

8. N. Yu. Kurepina, I. D. Rybkina, Geodesy and cartography 2, 33-41, DOI: 10.22389/0016-7126-2017-920-2-33-41.

9. N. Yu. Kurepina, I. D. Rybkina, N.In. Staseva, L. A.Magaeva, M. S. Gubarev, Geographic information-cartographic modelling of water availability in regions of Western Siberia, Conf, Novosibirsk, 239-243 (2015)

10. O. V. Lovtskaya, V. G. Vedukhina, N. Yu. Kurepina, S.V. Cilicia, Experience of generalization of the diverse and multi-temporal information in a project-oriented GIS Conf., Five plus, Barnaul, 42 (2013)

11. URL: http://legalacts.ru/doc/prikaz-mpr-rf-ot-25042007-n-111/.

12. D. Rybkina, Assessment of water supply security to the existing needs of the population and economy of regions of Siberia, World of science, culture, education, 327-332 (2012) 
13. I.D. Rybkina, N.Yu. Kurepina, N.In. Staseva, M.S. Gubarev, Geographic informationcartographic modelling of water availability for the purposes of water security and territories sustainable development, Conf., Vol. 1, 127-134 (2016)

14. D. Rybkina, N.In. Staseva, N. Yu Kurepina, The methodology of zoning of the river basin by the total anthropogenic load, Water sector of Russia: problems, technologies, management, 4, 42-52 (2011)

15. I.D. Rybkina, N.In. Staseva, L.A. Magaeva, V.F. Reznikov, M. S.Gubarev, N.Yu. Kurepina, Evaluation of the potential availability of surface and ground water resources of the population and economy of regions of Western Siberia, Conf., Barnaul, II, 252-260 (2014)

16. N.In. Staseva, I.D. Rybkina, Water resources of the Ob-Irtysh basin and use, Water resources, 41, 3 (2014)

17. URL: http://www.gisa.ru/44042.html. (2006)

18. A.D. Nikanorov, Academy of Sciences, 16, 992-998 (2014) 